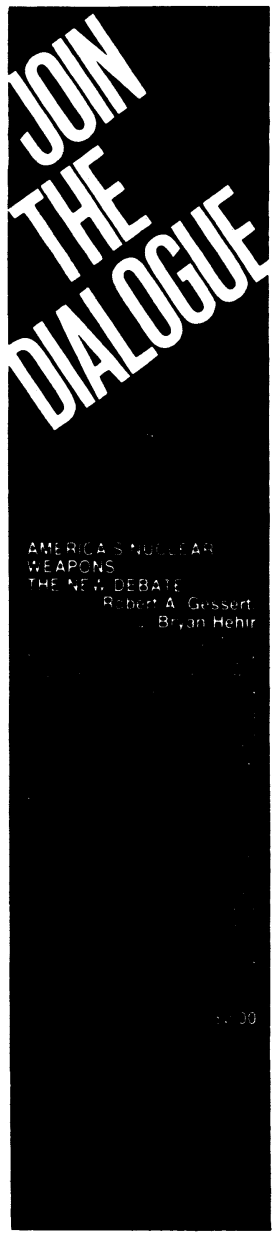

viewed as a feudal social system.

The reason these terms are so important is that in the United States, or at least for those reading the New York Times, there is immediate sympathy for the group on the "left" fighting the group on the "right."

...You may be interested to know that I am attempting to initiate an effort to accept a number of refugees from the war in Lebanon into the United States.

House of Representatives

Edward I. Koch

Congress of the United States

Washington, D.C.

\section{Of Solzhenitsyn and Cloistering}

To the Editors: Professor Molnar, who wrote on Solzhenitsyn (Books: "Solzhenitsyn: A Man Possessed," Worldview, May), certainly knows more about him than I do. However, I will dare to classify myself with Joseph Kraft, who, according to Molnar, " opines grotesquely" that "Solzhenitsyn hails from a culture considered backward by American standards and knows nothing of the relations between nations."

It is possible that Professor Molnar has led a more cloistered life than I. I experienced World War II in the Philippines, have been especially observant of our foreign policy ever since my liberation from the Japanese in 1945, and have traveled observantly and untouristically in eighty-three countries and colonies. I claim to be the only traveler to have interviewed all three of the following heads of state: Pandit Nehru of India, Nikita Khrushchev of the USSR, and the first syndic of tiny Andorra!

I also interviewed four former slave laborers of the Russians: a young German I met in West Berlin in 1951 who had worked for them five years; the Japanese secretary of the Hiroshima YMCA, in which city I met him in 1954; a Latvian Baptist minister I met in Riga in 1970 who had labored ten years in Siberia; and another Baptist pastor I met in Seattle in 1975 when he was visiting his brother here. They all told stories of great hardship. But not one of them was bitter. And the Japanese YMCA man said: "Well, Mrs. Bryant, a lot of those Communists are very sincere people."

When I traveled in Communist coun- tries I could claim kinship in Baptist churches. My Baptist brethren were not being persecuted as they had been under the Czars. One pastor told me: "Yes, it is all right for our young people to join the Young Pioneers and the Comsomols. There and in school they learn honesty and brotherhood. In fact, the Communists are doing so much for the people that I would become a Party member if it were not for their atheism."

And Metropolitan Nikolai, the second highest official of the Russian Orthodox Church, told me: "Formerly everyone, even atheists, had to belong to the Russian Orthodox Church. Now the atheists are free of the Church and the Church is free of the atheists, and it is a better situation." He estimated that, judging from the numbers of people taking communion, 50 per cent of the people still had ties with the Church.

Professor Molnar writes: "For Solzhenitsyn had pierced the great secret: the substance of Marxism is not the master's conceptual edifice, it is the hatred of God. Marxist atheism... is a declaration of total war on man, God's only accessible image."

In my view it is a disservice to mankind and his Creator to glorify Solzhenitsyn, who has done so much to increase hostility toward the USSR.

Alice Franklin Bryant

Seattle, Wash.

Thomas Molnar Responds:

Miss Bryant's letter suggests that there must still be people around who side with Anytos against Socrates and with Judas against Jesus. It is difficult to argue with such people, and I shall not attempt it. I only note that it does not occur to Miss Bryant that the Baptist pastor and Metropolitan Nikolai are agents, although involuntary, of the Communist Party and as such are full of praise for the regime.

But even more dangerous a person than a Communist aparatchik clad in priestly robes is an innocent blue-eyed American who travels to hell and reports back that the gardens are well-tended.

P.S. My "cloistered life" includes two years in concentration camps and visits to all continents: seventy-eight countries, admittedly five fewer than the eighty-three of which Miss Bryant boasts. 